This is the last draft of this article after the refereeing process and before publication.

Hurol, Y., Yuceer, H., Şahali, O., (2014) "Building Code Challenging the Ethics behind Adobe Architecture in North Cyprus" Science and Engineering Ethics. Vol:21. No:2. pp.381-399.

\title{
BUILDING CODE CHALLENGING THE ETHICS BEHIND ADOBE ARCHITECTURE IN NORTH CYPRUS
}

Yonca Hurol, Hülya Yüceer, Öznem Şahali

\begin{abstract}
Adobe masonry takes place within the vernacular architecture of Cyprus. Thus, it is possible to use this technology in a meaningful way on the island. On the other hand, although adobe architecture is more sustainable in comparison to other building technologies, the use of it is diminishing in North Cyprus. Application of Turkish building codes at the north part of the island made the use of adobe masonry complicated, because this building code asks use of reinforced concrete vertical tie-beams together with adobe masonry. Use of reinforced concrete elements together with adobe masonry causes problems in relation to climatic response of the building as well as causing other technical and aesthetic problems. This situation makes design of adobe masonry complicated and causes appearance of ethical problems of various types too. The objective of this article is to analyse the ethical problems due to the restrictive character of the building code by analysing two case studies and conducting an interview with an architect who was involved with adobe masonry in North Cyprus. According to the results of this article there are ethical problems at various levels in the design of the two cases. These problems are about the responsibilities of architects concerning architecture's social benefit, material production, aesthetics and affordability as well as presenting distrustful behaviour when the obligations of architects to their clients is concerned.
\end{abstract}

Keywords: adobe masonry, building codes, ethics of architecture, Cyprus

\section{INTRODUCTION}

Adobe masonry is known with its successful climatic response and tectonic outlook which combines various haptic colours of earth, curved corners, timber rafters sticking out of the walls and buttresses supporting the building mass. Including earth as a main component that is available and thus low-cost, it is also known as a technology preferred by the poor.

Adobe technology is also used in order to create meaning by referring to its historical origins. Hassan Fathy`s New Gourna Village, which was built between 1946 and 1952 in Egypt, is a 
well-known example of symbolically meaningful use of adobe with traditional arches and domes. A more contemporary example is Anna Heringer and Eike Roswag`s Hand-made School, which is in Bangladesh. This building won the Aga Khan Prize in 2007 (Lim, 2007). The architects aimed to achieve a sustainable building by using old traditional techniques together with current technologies, which are used in the historical village. For this purpose, the ground floor of the building was designed to be built by rammed straw-reinforced mud walls. The first floor has bamboo walls and rhythmically placed bamboo trusses. Materials and details play an important role in giving character to the spaces which have different functions. The use of local details gives a cultural and symbolic meaning to the building. The structure with such details, demonstrates its harmony with the environment. Figure 1 shows the plan, a section and the photographs of this building.
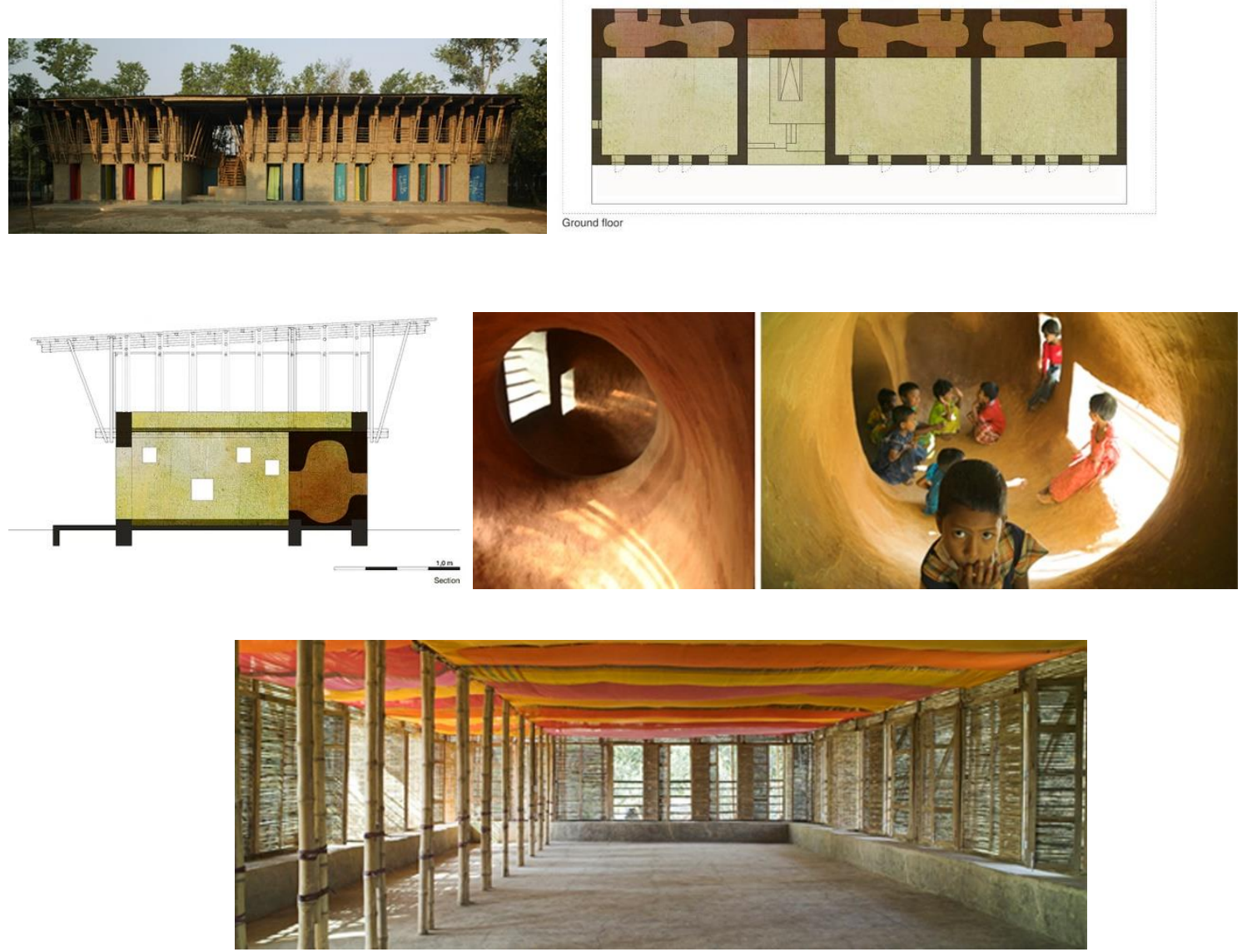

Figure 1. Plan, section and photographs of the Hand-made School in Bangladesh (by kind permission of Anna Heringer)

Although the use of adobe offers a sustainable, affordable and aesthetic architecture, its use has been diminishing as in the case in North Cyprus ${ }^{1}$, where adobe was vastly used as a building material in vernacular architecture of Cyprus. Since traditional adobe masonry is weak against earthquakes and moisture, many research have been carried out in order to

\footnotetext{
${ }^{1}$ Cyprus is the third largest island in the east of Mediterranean Sea. It was divided to north and south sectors in 1974 and mainly inhabited by Turks and Greeks correspondingly.
} 
improve the technical characteristics of adobe and many building codes have been prepared to make adobe buildings safe against earthquakes. There is an active building code in North Cyprus specifying the use of adobe masonry too. However, the contemporary adobe buildings of North Cyprus, which were built according to building codes, are not as successful as the vernacular architecture when sustainability, affordability and aesthetics are concerned.

The research problem considered in this article is the loss of many qualities of adobe when it is used according to the recommendations made by some building codes, which ask the usage of reinforced concrete elements together with adobe. Architects in North Cyprus either do not use adobe, or they ignore its qualities while realizing the requirements of building codes. The authors of this article think that this problem can also be analyzed from the point of view of architectural ethics because of the ignorance of sustainability, affordability and aesthetics of adobe masonry. Preparation of the building codes by risking the sustainability, affordability and meaningful use of adobe is also seen as ethically problematic.

The research objective of this article is to analyze the ethical problems due to the impact of building codes on adobe masonry design in North Cyprus. Changes in the construction process, climatic response, meaning in reference to vernacular architecture and the problems between the used materials are considered during the analysis of two case studies which were built according to the current building codes in Northern Cyprus. Methodology of the research is problem solving through the analysis of two case studies and an interview conducted with an architect, who was involved with one of the two case studies.

The article first presents the vernacular architecture in North Cyprus through the Mesaorian House. Then on-going research about improving the earthquake resistance and humidity problems of adobe masonry in various regions of the world is presented. Later the limitations brought by building codes and the effects of these codes on the qualities of adobe masonry are studied. Finally two recent case studies from North Cyprus; the Tatlisu Social Housing in Kyrenia and Komili Hotel in Büyükkonuk are analyzed to find out which qualities of adobe masonry were ignored while realizing the requirements of building codes and the ethical problems behind this ignorance is discussed.

\section{TRADITIONAL ADOBE BUILDING TECHNOLOGY IN CYPRUS}

Due to the prevailing climatic conditions and available materials, traditional building technology in Cyprus emerges as the use of mainly adobe and stone. Regarding adobe masonry, the component materials including clay soil, chopped straw and water are available all over the island, especially in the central plains. The clay content of soil varies from region to region, as does the colour, which is dependent on minerals such as iron oxide. Since farming is very common in rural areas of Cyprus, straw is also available from local suppliers. The adobe masonry is constructed by mud bricks of $43 \mathrm{~cm} \times 33 \mathrm{~cm} \times 7 \mathrm{~cm}$ which shrink nearly one $\mathrm{cm}$ after drying. Long hot-arid summers and thus shorter moderately cold winters offer perfect conditions for the adobe laying-drying process in the region. After drying, the mud bricks are commonly laid in the stretcher bond. The length of the brick constitutes the thickness of the wall as $42-44 \mathrm{~cm}$. The mortar used to lay the bricks is the same mud mixture 
as is used to make the brick itself. The water ratio is increased to achieve a better workability for spreading it between the courses which also helps better bonding of the bricks together. The adobe walls are finished with a thin layer of gypsum from interior and adobe mortar from exterior surfaces. With respect to material qualities and thickness of the adobe walls, heat is transferred slowly offering high insulation both from hot summer days and cold winters. Thus, it is still the most energy-efficient building material.

The vernacular adobe architecture seems to have similar characteristics in the region as it has been developed by the residents of the area according to their needs, culture, traditions and all conditions of the context. Yet, construction techniques and details may represent some slight differences depending on different variables such as availability of materials, dimension of spaces and openings, etc. Vernacular houses in North Cyprus, especially on the central plains - Mesaoria-, are constructed with adobe load-bearing walls which are usually connected with timber tie-beams.

These adobe houses comprise of adjacent spaces that are accessed through a semi-open, generally south-facing space. One of the most important architectural characteristics of these houses is the use of arches on the outer wall, defining the semi-open space, and in the main indoor space in order to carry the roof, as seen in Figure 2 and 3. These arches are made from stone and are built using a wooden formwork.
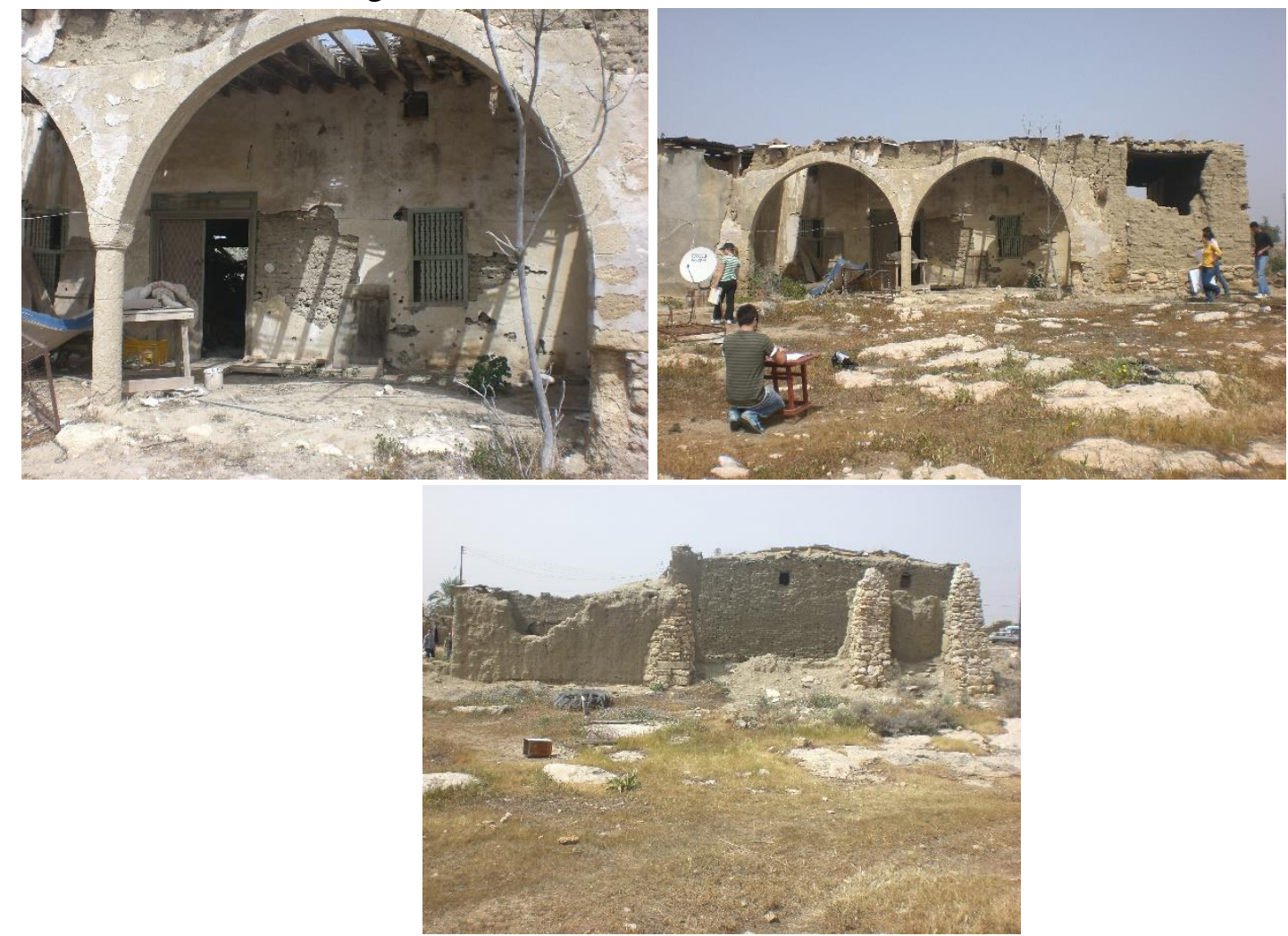

Figure 2. An outer hall Mesaorian house in Sandallar Village (photo by Hulya Yuceer) 

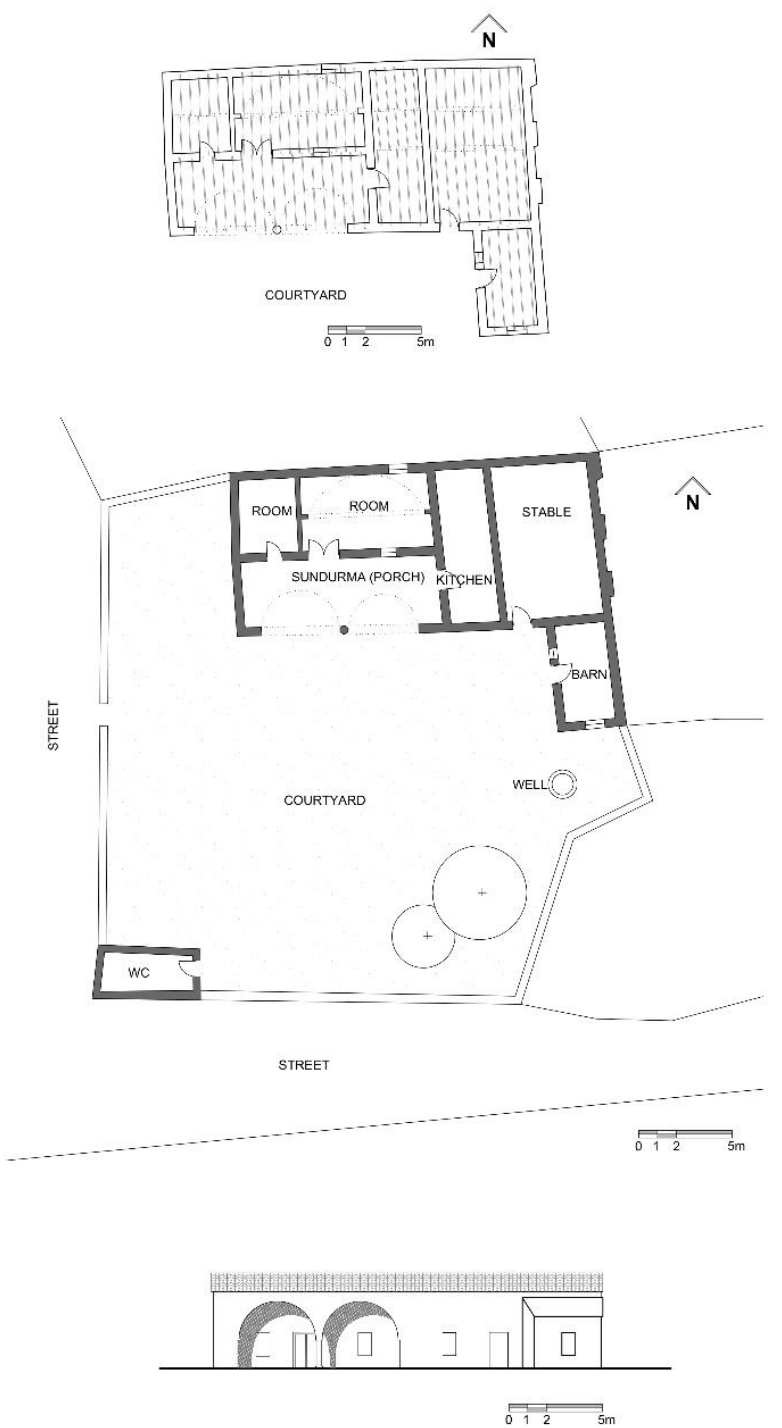

Figure 3. Drawings of a Mesaorian house in Sandallar Village (drawn by Hulya Yuceer)

Using adobe masonry brings some limitations regarding its construction, which have been solved with local experience throughout time and traced through construction details. For instance, since adobe is weak against moisture, foundations and lower layers of buildings are made out of stone. The adobe construction usually has continuous footings which are about $50 \mathrm{~cm}$ high from ground level. The footing acts as a damp proof course and prevents the erosion of adobe by rising dampness. In cases where longer and/or higher walls are necessary, they are supported by either stone or adobe buttresses. In order to increase stability, the corners of the walls are interlocked with the help of cut stone masonry. Another limitation is related with size and construction of openings inside the adobe walls. Since majorly wooden lintels are used to span the openings, their sizes are small (Dinçyürek, Mallick, Numan, 2003).

Mesaorian houses have either a flat roof or a pitched roof. The flat roofing system contains a layer of earth, straw, bamboo sticks and mashes on rafters. (Dinçyürek, Mallick, Numan, 
2003) The pitched roof system is made up of terracotta tiles on the surface with layers of mud, rushes, cane matting and timber beams underneath (see Figure 4). Many of these building elements are frequently used in contemporary architecture in order to achieve a symbolic value.

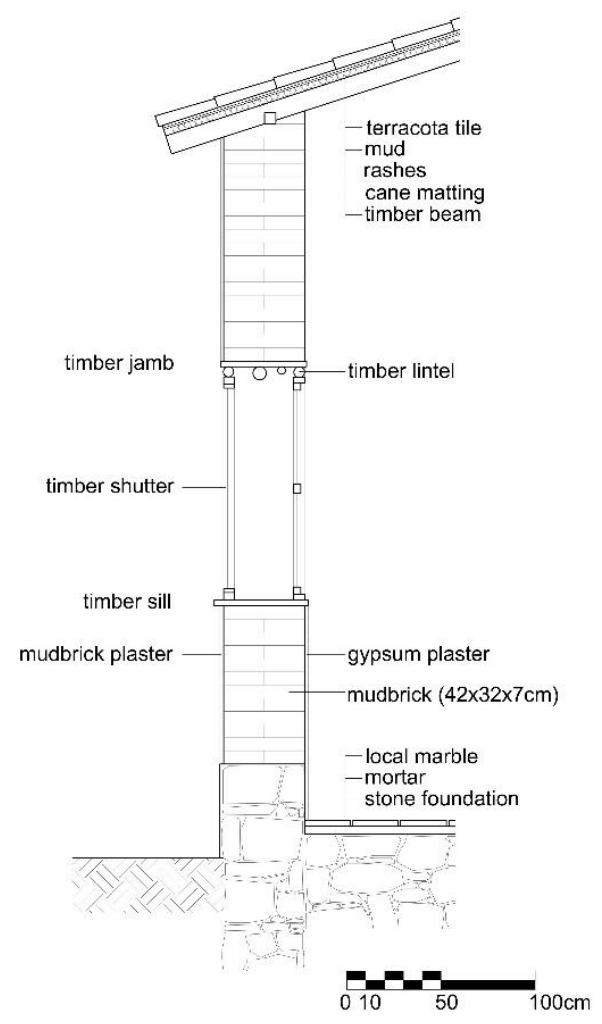

Figure 4. System detail of an adobe house in Mesaoria region. (drawn by Hulya Yuceer)

Though used extensively in the past in Cyprus, the construction of adobe buildings dramatically declined in the 1960's with the introduction of reinforced concrete building technology. Yet, there has been an increasing demand to live in adobe houses in Cyprus since they are climatically responsive and thus more beneficial in respect of energy usage since the new building technologies cannot ensure the advantages of adobe technology.

As stated in several sources, it is commonly known that incorporating those features which emulate vernacular architecture results in a more ecological and sustainable architecture (Dinçyürek, Mallick, Numan, 2003; Özay, 2005; Günçe, Ertürk, Ertürk, 2008; Oktay, 2002). Accordingly, the use of adobe technology and the correct interpretation of the design principles of vernacular architecture help to meet the expectations of people looking for houses that are climatically responsive and thus more beneficial in respect of lower energy consumption. The aesthetics achieved through representing the vernacular architecture is another advantage of this approach.

\section{ON GOING RESEARCH ON IMPROVING ADOBE MASONRY CONSTRUCTION}


Masonry construction technology has a long history. It was one of the first building techniques used by human beings. It is undeniable that each country, each culture - even the lost ones - have adobe masonry in their past. On the other hand, it is commonly known, today, that adobe masonry structures are weak in respect of earthquakes and moisture.

Knowing the advantages and disadvantages of using adobe a great deal of research has been carried out in an attempt to improve the quality of adobe buildings. This research can be categorized as follows: improving material quality, improving building technique through the use of buttresses, cross-walls and timber reinforcement and improving building technique by using steel to reinforce the adobe.

\subsection{Improving the Material Quality}

Researchers suggest that people wishing to build using adobe test the adobe before using it with the help of the dry strength test or the roll test, which can easily be done by anybody. There is also ongoing research being carried out in respect of improving the technical characteristics of adobe by adding other materials. The addition of lime and gypsum to earth, for example, has been shown to, at least, triple the strength of the adobe against compression. This material is known as gypsum stabilized earth or 'alker'. Durability and workability is also increased with the addition of these materials. There are also human health benefits because of the elimination of the moisture problem as a result of the increased water resistance (Işık, 2008).

\subsection{Improving Building Technique by using Buttresses, Cross-walls and Timber Reinforcement}

It is known and shown through research that the use of cross-walls in interior and exterior wall intersections, buttresses on the corners of the building, timber vertical tie-beams in long walls, timber trusses over openings, vertical and horizontal reinforcement with bamboo, cane, chicken wire etc, the application of plastering, having reinforced concrete foundations, controlling the size and layout of openings, increasing wall thickness proportional to wall height and length, having only one floor, using a light roof system and not having large rooms increases the earthquake resistance of adobe buildings (Dowling, Samali, Li, 2005; Central Asia Earthquake Safety Initiative, 2005; Blondet, Garcia, Brzev, Rubinos, 2011).

\subsection{Improving Building Technique through using Steel for Reinforcing Abode}

Steel is used for reinforcing all types of masonry structures including adobe masonry. However, since the bond between the steel and adobe has to be provided, the mortar should contain both cement and earth simultaneously. Thus, the three types of reinforced adobe shown in Figure 5 are categorized thus: (Fodi, Bodi, 2011)

- Concrete filled cavity wall: The cavity left between two adobe walls is filled with grout containing steel reinforcement. 
- Wall with vertical tie-beams: Wall intersections are organized as concrete tie-beams in the vertical direction and the required reinforcement is calculated according to the loads affecting the system.

-Replacement of steel in mortar: Steel bars are placed within the mortar in vertical and horizontal directions and the required reinforcement is calculated according to the loads affecting the system.

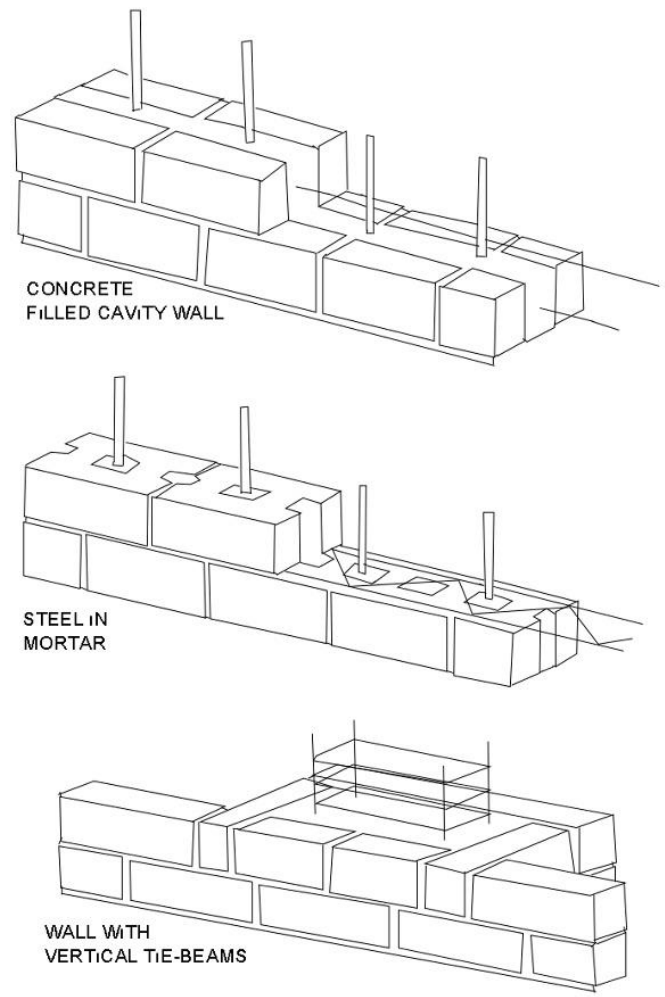

Figure 5. Three types of reinforced masonry (drawn by Yonca Hurol)

These steel reinforced masonry structures are analogous with reinforced concrete frames. Only their construction methods are different. Frame structures are built before the partition walls. However, vertical tie-beams are built after building the masonry walls. This technology is also known as confined masonry. In all types of steel reinforced masonry, either steel is combined with masonry or steel and concrete are added after building the masonry walls.

Different building codes make different recommendations concerning the improvement of adobe masonry technology.

\section{LIMITATIONS BROUGHT BY THE BUILDING CODES}

Many countries` building codes cover masonry structures, such as the USA, Turkey, the Turkish Republic of Northern Cyprus, Pakistan and India. Some countries have specialized 
building codes in respect of adobe masonry. Mexico, Peru and New Zealand are amongst these countries. However, since most of the adobe buildings of the world have been designed and built by people and not by professionals, some of these codes aim to support and help people to achieve a higher standard of building and some others aim to bring restrictions to adobe buildings, which have been designed by professionals. For example, the Mexican adobe building code aims to help and inform people, because it provided practical information such as having buttresses, bond beams etc, in order to improve the earthquake resistance of adobe buildings (New Mexico Earthen Building Materials Code, 2009). On the other hand, New Zealand`s Earth Building Standards covers the mathematical analysis methods for improving the earthquake resistance of reinforced and unreinforced adobe masonry for structural engineers (New Zealand Edict of Government, 1998.a,b,c).

The Cypriot earthquake zones can be seen in Figure 6. North Cyprus, which is subject to earthquake risk mainly around the town of Famagusta, does not have a building code as yet. Turkish building codes are used in North Cyprus.

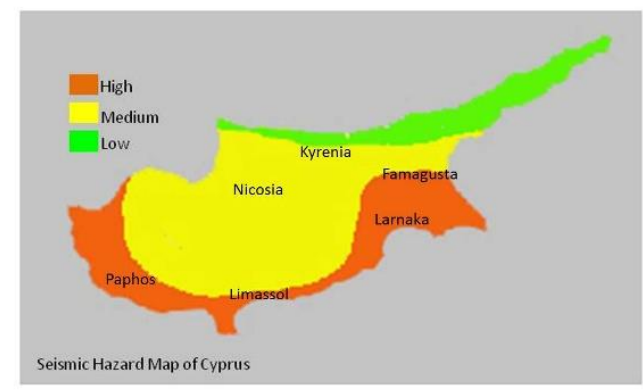

Figure 6. Earthquake zones of Cyprus (redrawn by Oznem Sahali, source: Eurocodes Committee, 2004)

The Turkish building code does not ask for a mathematical analysis for adobe structures. However, the number of storeys, the height of floors, wall thickness, the use of reinforced concrete bond beams/slabs and the layout of openings are specified. Furthermore, if the length of any wall is more than 4.5 meters, the building code demands the use of reinforced concrete vertical tie-beams every 4 meters. This building code also suggests the use of reinforced concrete vertical tie-beams on the corners of buildings, at the intersections of walls and at both sides of all openings in order to increase the earthquake resistance of all masonry buildings (Ministry of Public Works and Settlement Government of the Republic of Turkey, 2007).

The presence of reinforced concrete vertical tie-beams and bond beams turn most of the adobe buildings into reinforced masonry buildings. Limiting professional applications of 
adobe with this type of reinforced adobe decreases the possibility of forming an aesthetic relationship with the historical Cypriot Mesaorian houses. This is a common view held by local architects. Using reinforced adobe might also cause problems in the climatic response of the building. It might create some technical problems, such as the low bondage between earth based and cement based materials.

On the other hand, there are other building codes, which do not force the use of reinforced masonry. For example, the building code of the Cyprus Republic asks for the mathematical analysis of both reinforced and unreinforced masonry applications, without specifying any difference for adobe masonry (Eurocodes Committee, 2004). Mexico`s building code seems to be unique in guiding design in increasing earthquake resistance without using structural elements such as reinforced concrete or vertical tie-beams (New Mexico Earthen Building Materials Code, 2009).

\section{PROBLEMS DUE TO THE PRESENCE OF REINFORCED CONCRETE STRUCTURAL ELEMENTS}

The use of reinforced concrete tie-beams in adobe buildings might cause the following problems:

a. Climatic response might be lowered because of the heat loss due to conduction, if the vertical tie-beams are as thick as the walls and not covered by adobe walls.

b. If the structure becomes a reinforced concrete frame with adobe partition walls, affordability decreases and the construction process changes in such a way that it will not be possible for poor people to build their own houses.

c. The construction problem in respect of suggesting the simultaneous use of modern and traditional construction techniques renders adobe technology to non-viable. If it is necessary to use the reinforced concrete of modern building techniques then why should anyone use adobe, which can be built by local people?

d. If the vertical tie-beams are as thick as walls and not covered by adobe walls, visibility of these elements change the image of the building and creating meaning through representation of historical architecture becomes more difficult. Thus, the masonry architecture with reinforced concrete vertical tie-beams, such as Demir Holiday Village of Turgut Cansever has been criticized negatively because of the presence of concrete surfaces on the stone facade, although this building has the price of Aga Khan in 1992 (Khosla 1992). In this project, construction consist of loads bearing stone walls, wood for slabs and roofs and exposed concrete for tie beams.

e. Cracks can occur between the reinforced concrete vertical tie-beams and adobe walls, if cement is not mixed into adobe. The technical problem due to the weak bondage between earth based and cement based materials is not specified in the Turkish building code. However, the New Zealand building codes (1998.a,b,c) regarding adobe construction specifies the problem and gives details of how to deal with and solve the problem. 


\section{CASE STUDIES}

This article presents the Tatlisu Social Housing complex and the Komili Hotel in Northern Cyprus, which have problematic applications of reinforced adobe masonry.

\subsection{Tatlisu Social Housing, Kyrenia, North Cyprus}

According to the interview conducted with the Turkish Cypriot architect Turusan Aslankelle, the Tatlisu Social Housing project in the state of North Cyprus, was a low cost project, which was built by many sub-contractors. Since there was a demand for adobe houses, these buildings were initially planned and designed as adobe buildings. Later, however, because of the building code requirements they were transformed into reinforced adobe buildings with vertical reinforced concrete tie-beams as is shown in Figure 7. The proportions of the buildings and the stone cover on the corners of the buildings make these buildings reminiscent of traditional Mesaorian houses. The arches, which were in the initial design, were not realized.


Figure 7. Photo of the complete building, perspective at the project stage and the plans of the houses in the Tatlisu Social Housing Project. (photo and drawings by Oznem Sahali, perspective by Turusan Aslankelle)

Aslankelle, who prepared the drawings of the project, states that: 
"...Since there was not any building regulations about constructing simple adobe buildings in North Cyprus, it would not be possible to get approval from local authorities at the beginning. It is decided to change construction system from load-bearing adobe to composite construction system."

However, according to Aslankelle, during the construction process, the adobe walls were replaced with brick walls and in order to keep the adobe outlook the facades of the buildings were covered with earth based plaster. This should have been done in order to use the most common construction technology in North Cyprus.

The owners of the buildings, who bought these houses, were thinking that they were real adobe houses, which work very well in the Cypriot climate. Although nobody told them that they were adobe buildings, the image of the buildings made people think like this. Later when they were told that the buildings were constructed from reinforced brick masonry, they were upset. The architect Aslankelle stated that: "The project became aesthetically successful in terms of creating simple adobe village house effect. Moreover, most of the clients asked if the building material is really adobe or not. Unfortunately, the clients got a little bit disappointed when they learned that the buildings are not built out of adobe."

According to the authors' observations of the building site, the majority of these buildings have been re-plastered with a cement based plaster. Thus, the image of the adobe building is also lost.

\subsection{Komili Hotel, Büyükkonuk, Famagusta, Cyprus\}

Büyükkonuk is an eco-village in North Cyprus. Since eco-tourism is the main activity of the village, it is very common to see some traditional stone or adobe buildings in the village, e.g the Komili Hotel buildings, which are composed of six very simple adobe buildings as is shown in Figure 8, represent one of these.

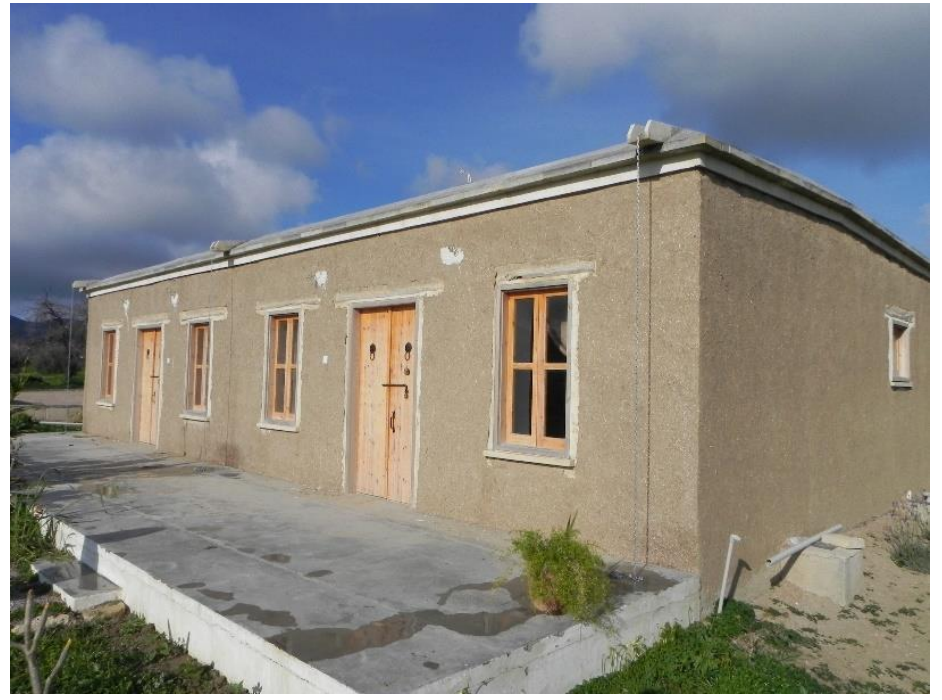

Figure 8. One of the Komili Hotel buildings (Photo by Hulya Yuceer) 
As is seen from Figure 8, only the scale, proportions and colour of these buildings are reminiscent of historical Mesaorian houses. The designers have not used any of the typically historical structural elements such as e.g. arches.

Since the Komili Hotel was a professionally designed project, it was also subject to the building code requirements used in North Cyprus. Thus, it became necessary to use reinforced concrete vertical tie-beams within the adobe walls because the dimensions of spaces were larger than 4.5 meters. These tie-beams were concealed within the adobe walls.

The main problem with the structure of the Komili Hotel is a technical one arising from the weak bondage between the cement based and earth based materials. The adobe surfaces surrounding the reinforced concrete vertical tie-beams were disintegrating because of this weak bondage (see Figure 9.)

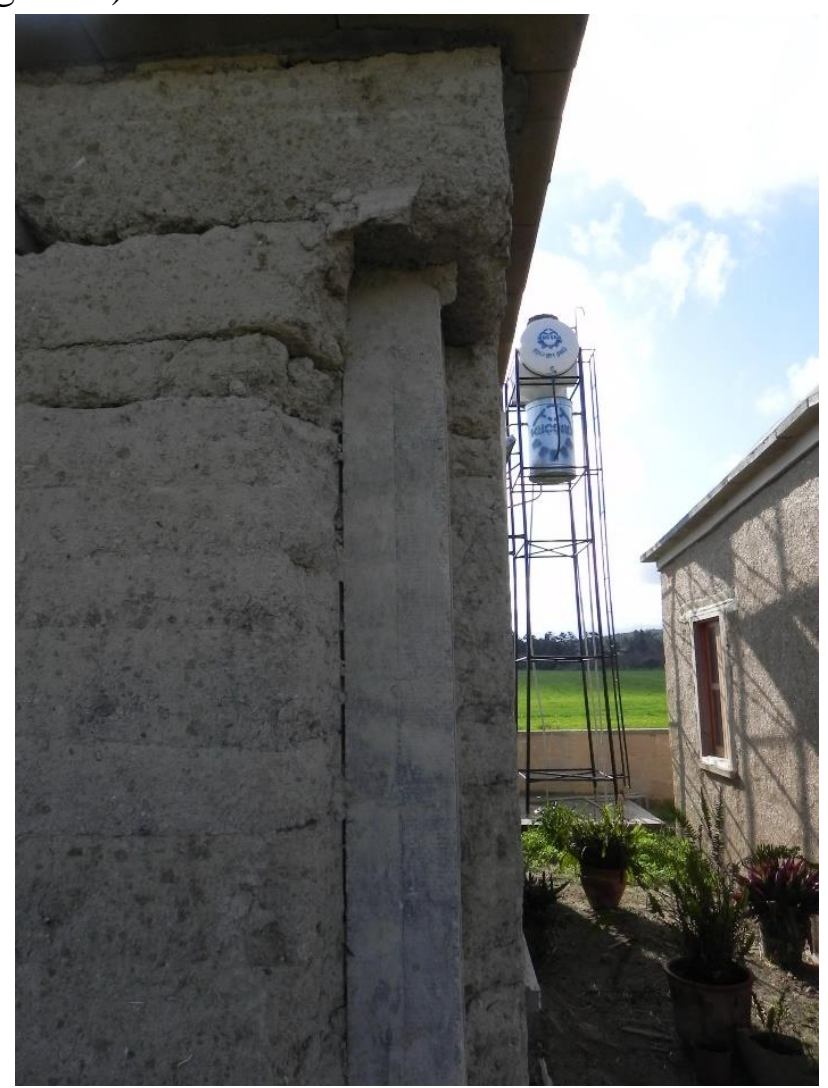

Figure 9. The reinforced concrete vertical tie-beam within the adobe wall (Photo by Hulya Yuceer)

\section{DISCUSSION OF THE ETHICAL PROBLEMS IN THE TWO CASES}

Ethical problems due to taking building codes about adobe masonry literally and ignoring the historical qualities of this structural material can be analyzed through the following five lenses of architectural ethics initiated by Wasserman, Sullivan and Palermo (2000):

a. The lens of architecture`s purposefulness and social benefit: If the climatic performance of the building is lowered, this means that the architect is ignorant about the issues of sustainability and climate change (Brown, 2013; Williams, 2012, Fisher, 
2008) which in turn effects the social benefit. Since the Tatlisu Social Housing has vertical tie-beams, which have the same thickness with the walls, this causes heat loss through conduction and makes these buildings weaker than traditional adobe buildings against climate. However, this problem does not exist in Komili Hotel, because the vertical tie-beams are buried in the adobe walls.

b. The lens of material production: If the affordability of the building and construction quality decreases, this means that the architect is ignorant about material production. Since construction quality is low both in Tatlisu Social Housing and Komili Hotel, it can be stated that material production was ignored. By designing the building as a villa, the affordability of Tatlisu Housing was decreased considerably in comparison to traditional adobe architecture.

c. The lens of aesthetics: Wasserman, Sullivan and Palermo (2000: 85, 86) say that "in its role of giving form, beauty, image and meaning to societal expectations, aspirations or needs we look to discern architecture`s aesthetic embodiment of ethical force... The architect is responsible ethically for knowledge of the theoretical and historical sources of form, beauty and appearance, and possessing the skills and creativity to generate them." Tatlisu Housing and Komili Hotel buildings are not pretentious buildings about aesthetics. Still, the Tatlisu Housing is seen as successful about representing vernacular architecture by the architect Aslankelle. However, since the appearance of these buildings made their clients think that they were real adobe buildings, there is an ethical problem in their image. Clients were attracted because of this confusion. This can be seen as a distrustful behaviour in terms of the obligations of an architect to his/her clients (Fisher, 2010: 65-68).

d. The lens of architecture's rhetoric and ideologies: Decreasing the affordability of adobe construction can be seen as an ideological and ethical problem, because a technology which is used by poor, starts being used in the production of objects of consumer society.

e. The lens of praxis: The distrustful behaviour in terms of the obligations of an architect to his/her clients is also a praxis problem, which might cause trouble for the architectural office involved.

On the other hand, preparation of restrictive building codes, which invite many architectural and ethical problems, can also be criticized from the ethical point of view. Since there are many different ways of improving adobe, the building codes should be open for the use of any of these improvements. Spector (2001) gives reference to Seismic Safety Commission of Sacramento (1995) and says that such problems have to be solved before the preparation of the building code:

"We could build nothing but square one story houses with few windows on flat ground well away from any known fault; that would minimize earthquake risk, but would significantly reduce the livability of our homes. Or we could build 'disposable' buildings intended to be replaced after the first damaging earthquake. The answer lies somewhere between these extremes, and the Commission believes the question must be answered at a policy level 
before building codes and state law can adequately address the practical issues of improving buildings."

\section{CONCLUSION}

Although the traditional adobe technology has many advantages such as being sustainable, affordable and aesthetic, it cannot be used as it was used before because of its low earthquake resistance and humidity problems. Because of this, there are many research made to get rid of the disadvantages of the adobe technology.

One of the major tools to improve building technologies is the building codes. Thus, the building codes of countries, which have seismic problems, consider adobe masonry technology, especially if this technology exists in their history. Some of these codes are more flexible towards the use of different approaches to adobe masonry, whilst some of them are rather restrictive by imposing the use of a certain solution. The building code used in North Cyprus is a restrictive one because it recommends the use of reinforced concrete vertical tiebeams together with adobe masonry walls and accepts no other solutions. This strict diversion from the traditional technology brings safety against earthquakes, but invites many ethical problems in the architectural design practice.

The two contemporary case studies: Tatlisu Social Housing in Kyrnia and Komili Hotel in Büyükkonuk, which are analysed within this article show that these contemporary adobe buildings are less sustainable and less affordable in comparison to traditional adobe masonry buildings. Their aesthetic value is lower than the aesthetic value of vernacular adobe examples. They also have construction problems which cause cracks on the walls.

Sustainability problem could have been avoided by designing appropriate details between the reinforced concrete tie-beams and adobe walls. Construction problems could have been solved by mixing adobe with cement. Hiding vertical tie-beams could help in improving the aesthetic quality of such contemporary adobe buildings. However, since the quality of the two case studies is lower than the traditional examples, it can be said that there is a multidimensional ignorance of various ethical responsibilities (including consideration of social benefit, material production, aesthetics, affordability and obligations to the client) in the design of these two cases.

In addition, preparation of a restrictive building code, which forces architects to use certain types of building elements, without considering the general improvement of building quality also contains ethical problems. It is a better strategy for building codes to be more flexible to enable different approaches to structural safety, which in turn enables better design. At least the code can be open to different types of reinforced masonry rather than imposing a certain type. Solution of the problem of low building quality of adobe buildings and the related ethical problems of architecture lies in the preparation of a less restrictive building code and handling the problem before preparation of the building code while determining the philosophy of it. 


\section{REFERENCES}

ACI 530-02/ASCE 5-02/TMS 402-02, (2002) Masonry Standards Joint Committee, Building Code Requirements for Masonry Structures, https://engineering.purdue.edu/ ramirez/CE479/FALL05/MasonryBuildingCode1-3-02.pdf (Accessed on 5.9.13)

Blondet, M., Garcia, G.V.M., Brzev, S., Rubinos, A., (2011) Earthquake-Resistant Construction of Adobe Buildings: A Tutorial. $2^{\text {nd }}$ Edition. EERI/IAEE World Housing Encyclopedia.

Brown, D.A., (2013) Climate Change Ethics - Navigating the Perfect Moral Storm. London: Earthscan.

Central Asia Earthquake Safety Initiative, (2005) Seismic Safety for Adobe Homes. www.nset.org.np/nset/html (used on 26.10.13)

Dincyurek, O., Mallick, F., Numan, I., (2003) "Cultural and Environmental Values in the Arcaded Mesaorian Houses of Cyprus” Building and Environment. 38. pp.1463-1473.

Dowling, D., Samali, B., Li, J., (2005) “An Improved means of Reinforcing Adobe WallsExternal Vertical Reinforcement” Sismo Adobe. PUCP. Lima Peru. May 16-19.

Eurocodes Committee- Scientific and Technical Chamber of Cyprus under a Ministry of Interior`s Program, (2004) CYS Annex to CYS EN 1998-1, Eurocode 8- Design of Structures for Earthquake Resistance. http://www.cys.org.cy/images/public/eurocodes (used on 20.10.13)

Fisher, T., (2008) Architectural Design and Ethics. UK: Architectural Press.

Fisher, T., (2010) Ethics for Architects - 50 Dilemmas of Professional Practice. NY: Princeton Architectural Press.

Fodi, A., Bodi, I., (2011) "Basics of Reinforced Masonry." Concrete Structures. Vol 12. pp.69-77. Fib.bme.hu/.../vb2011\%20angol\%20\%20FODI-BODI\%20page69-77.pdf (used on 26.10.13)

Gunce, K., Erturk, Z., Erturk, S., (2008) "Questioning the Prototype Dwellings in the Framework of Cyprus Traditional Architecture" Building and Environment. 43. pp.823-833.

Isik, B., Tulbentci, T., (2008) "Sustainable Housing in Island Conditions Using Alker gypsum stabilized earth: A Case Study from Northern Cyprus" Building and Environment. 43. pp.1426-1432.

Khosla R.,(1992), “Demir Holiday Village,Bodrum,Turkey” Technical Review Summary, 1136.TUR. 
Lim, J.C.S, ( 2007) “Hand-Made School Rudrapur, Bangladesh”, On Site Review Report, 3392.BAN.

Ministry of Public Works and Settlement Government of the Republic of Turkey. (2007)

Seismic Performance Evaluation of Dual Reinforced Concrete Systems Design According to Turkish Seismic Code. (Trans: E.Y. Karc1) http://www.belgeler.com/blg/22lc/seismicperformance-evaluation-of-dual-reinforced-concrete-systems-design-according-toturkish-seismic-code (used on 26.10.13)

New Mexico Earthen Building Materials Code (2009) www.nmcpr.state.nm.us/nmac/parts/title14/14.007.0004.htm (used on 29.10.13)

New Zealand Edict of Government (1998.a) NZS 4299: Earth Buildings not Requiring Specific Design https://law.resource.org/pub/nz/ibr/nzs.4299.1998.pdf (used on 29.10.13)

New Zealand Edict of Government (1998.b) NZS 4298: Materials and Workmanship for Earth Buildings. https://law.resource.org/pub/nz/ibr/nzs.4298.1998.pdf (used on 29.10.13)

New Zealand Edict of Government (1998.c) NZS 4297: Engineering Design of Earth Buildings. https://law.resource.org/pub/nz/ibr/nzs.4297.1998.pdf (used on 29.10.13)

Oktay, D., (2002) "Design with the Climate in Housing Environments: An Analysis in Northern Cyprus" Building and Environment. 37. pp.1003-1012.

Ozay, N., (2005) "A Comparative Study of Climatically Responsive House Design at Various Periods of Northern Cyprus Architecture" Building and Environment. 40. pp.841-852.

Seismic Safety Commission, (1995) Northridge Earthquake Turning Loss to Gain, Report no: 95-01. Sacramento Seismic Safety Commission, State of California.

Spector, T., (2001) The Ethical Architect - The Dilemma of Contemporary Practice. NY: Princeton Architectural Press.

Wasserman, B., Sullivan, P., Palermo, G., (2000) Ethics and the Practice of Architecture. Canada: John Wiley and Sons.

Williams, J., (2012) Zero Carbon Homes - A Road Map. London: Earthscan. 